\title{
Heavy Metal Concentrations in Vegetables Cultivated and Sold in Machakos Municipality, Kenya
}

\author{
${ }^{* 1}$ TOMNO, RM; ${ }^{2}$ KITULU, L; ${ }^{3}$ NZEVE, JK; ${ }^{4}$ WASWA, F; ${ }^{1}$ MAILU, SN; \\ 5SHITANDA, D \\ ${ }^{* 1}$ Department of Physical Sciences, ${ }^{3}$ Department of Environmental Sciences, ${ }^{5}$ Department of Mechanical Engineering, Machakos \\ University, P.O. Box 136 - 90100 Machakos, Kenya; \\ ${ }^{2}$ Department of Environmental Sciences, ${ }^{4}$ Department of Agricultural Science and Technology, Kenyatta University, P.O. Box $43844-$ \\ 00100 Nairobi, Kenya; \\ *Corresponding Author Email: tomnorose@gmail.com
}

\begin{abstract}
Heavy metal contamination of vegetables is a key aspect of food quality assurance since vegetables form a substantial proportion of the daily human diet. Health risks in urban populations due to exposure to heavy metals are on the increase because of the consumption of vegetables irrigated with wastewater. This study analyzed the concentration of $\mathrm{Cd}, \mathrm{Cu}, \mathrm{Pb}, \mathrm{Zn}$ and $\mathrm{Cr}$ in spinach and kales grown using contaminated water of the Mitheu urban stream and those sold within Machakos municipality. Vegetable samples were collected once per month for a period of four months starting from June to September 2019. The mean heavy metal concentrations obtained were $0.013-3.19 \mathrm{mg} / \mathrm{kg}$, $0.468-1.706 \mathrm{mg} / \mathrm{kg}, 0.02-0.368 \mathrm{mg} / \mathrm{kg}, 5.78-26.7 \mathrm{mg} / \mathrm{kg}$, and $0.104-14.0 \mathrm{mg} / \mathrm{kg}$ for $\mathrm{Cd}, \mathrm{Cu}, \mathrm{Pb}, \mathrm{Zn}$ and $\mathrm{Cr}$ respectively in kale samples from the different sampling sites. The heavy metal mean concentrations in spinach were 0.055 $-0.575 \mathrm{mg} / \mathrm{kg}, 3.79-5.55 \mathrm{mg} / \mathrm{kg}, 0.098-1.49 \mathrm{mg} / \mathrm{kg}, 8.32-20.7 \mathrm{mg} / \mathrm{kg}$ and $0.368-4.43 \mathrm{mg} / \mathrm{kg}$ for Cd, $\mathrm{Cu}, \mathrm{Pb}, \mathrm{Zn}$ and $\mathrm{Cr}$ respectively. The mean concentrations of $\mathrm{Cd}, \mathrm{Pb}, \mathrm{Zn}$ and $\mathrm{Cr}$ in both spinach and kales in some of the sampling sites were above WHO permissible levels for heavy metals in vegetables for human consumption. However, the mean concentration of $\mathrm{Cu}$ was below WHO recommended levels. Consumption of these vegetables therefore poses a health risk to the consumers. There is need to create public awareness on the dangers of consuming contaminated vegetables. Additionally, measures to curb heavy metal pollution in Mitheu stream should be taken by the County Government of Machakos.
\end{abstract}

DOI: $\underline{\text { https://dx.doi.org/10.4314/jasem.v24i12.3 }}$

Copyright: Copyright $(\mathrm{C} 2020$ Tomno et al. This is an open access article distributed under the Creative Commons Attribution License (CCL), which permits unrestricted use, distribution, and reproduction in any medium, provided the original work is properly cited.

Dates: Received: 11October 2020; Revised: 13 November 2020; Accepted: 24 November 2020

Keywords: Vegetables, Heavy metals, Contamination, Assessment

Vegetables are an important source of vitamins, minerals, and fiber necessary for human nutrition and health (Wong et al., 2019;Bett et al., 2019). The popularity of leafy vegetable farming in urban areas of developing countries will continue to increase due to the ready market provided by the ever-increasing population (Kacholi, 2018; Kombe, 2005; Balkhair and Ashraf, 2016). However, consumption of vegetables in the urban areas has increasingly become a concern to both consumers and city authorities due to possible contamination occasioned by use of contaminated urban streams for irrigation. Studies indicate that urban effluent contains high concentration of heavy metals, which are easily taken up by vegetables thus posing a health risk to consumers (Hussain et al., 2019; Shaheen et al., 2019). Industrial processes such as municipal sewage and solid waste disposal, vehicular traffic, pesticide use, and inappropriate use of fertilizers contribute to increased concentration of heavy metals in the environment (Bi et al., 2018).

*Corresponding Author Email: tomnorose@gmail.com
Food contaminated by heavy metals affects human wellbeing and can drain a significant portion of the fundamental supplements in the body (Khan et al., 2008 ; Ray and Kanti Ray, 2009).

Heavy metals are responsible for diminishing immunological resistances, degradation of intrauterine development, malfunctioning psychological faculties, disabilities associated with malnutrition and high predominance of upper gastrointestinal cancer (Arora et al., 2008). Several other studies also show the potential risk of accumulation of heavy metals in plants to human health (Chauhan and Chauhan, 2014; Balkhair and Ashraf, 2016; Alghobar and Suresha, 2017). Heavy metals such as $\mathrm{Cd}$ and $\mathrm{Pb}$ have been shown to be carcinogenic (Jaishankar et al., 2014). Other metals like $\mathrm{Cu}$ and $\mathrm{Zn}$ are basic supplements for human wellbeing yet can be toxic in high concentrations (Harmanescu et al., 2011; Shaheen et al., 2016; Ikenaka et al., 2014). 
Human exposure to heavy metals is thus a public health concern all over the world and has attracted the attention of researchers, health and nutrition officers (Adedokun et al., 2016). The permissible and hence safe limits of $\mathrm{Cd}, \mathrm{Cu}, \mathrm{Pb}, \mathrm{Zn}$ and $\mathrm{Cr}$ by the World Health Organization (WHO) are $0.2,10,0.2,5.0$, and $2.3 \mathrm{mg} / \mathrm{L}$ respectively (Stan, 2009). However, their potential toxicity, persistent nature and bioaccumulation behavior necessitates a routine analysis of food items to ensure they are within permissible limits. This study focused to determine the levels of $\mathrm{Cd}, \mathrm{Cu}, \mathrm{Pb}, \mathrm{Zn}$ and $\mathrm{Cr}$ in spinach and kales grown using water from Mitheu urban stream in Machakos municipality and those sold in the market and supermarkets in Machakos town. The results will be useful in raising awareness of potential health hazards of these vegetables and in highlighting the need for the County government to invest in sustainable effluent management and occupational safety and health.

\section{MATERIALS AND METHODS}

Study Area and Sampling Sites: This study was carried out in Machakos municipality in Kenya. The vegetable farms are located along Mitheu stream as indicated in figure 1. Much of the domestic and municipal effluent generated within the town is drained into Mitheu stream. As would be expected, much of the vegetable grown along this stream is sold from the municipal open-air markets. Four vegetable sampling sites were selected along Mitheu stream and three market outlets within Machakos town (i.e the main open-air market (OAM) and two selected supermarkets (SPM 1 and SPM 2). The open-air market and the supermarkets are retail markets for different types of food items. Sampling sites along the stream were site A, site B, site $C$ and site D. Site D was farms upstream of Mitheu stream where the Machakos town wastewater sewer lines were vandalized releasing raw sewage directly into Mitheu stream. Site $\mathrm{C}$ was at farms adjacent to the wastewater treatment plant, site B was farms just downstream of the treatment plant while farms further downstream was site A. Irrigation of vegetables using wastewater is actively taking place at the four sampling points along the stream.

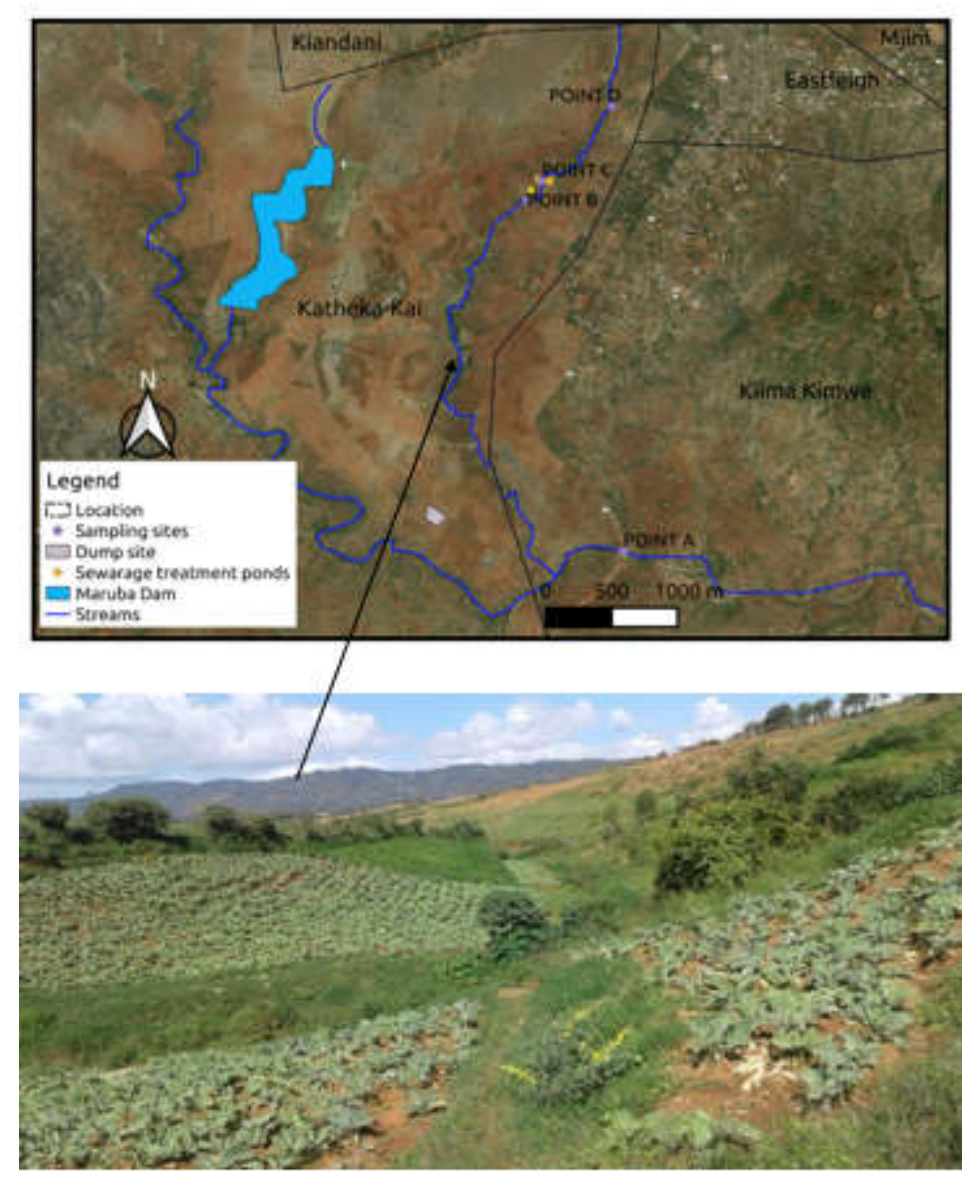

Fig 1: Map of the study area showing sampling sites and vegetable farms 
Sampling: Vegetable samples of spinach (Spinaciaoleracea) and kales were randomly bought from the farmers farming in the selected sites along the urban stream and from the selected market sites. The samples were put in clean polyethylene bags, welllabeled to indicate the site and date of sampling and transported to Kenya Plant Health Services (KEPHIS) Chemistry and Analytical certified laboratory, Nairobi for heavy metals analysis. Sampling was done once each month for a period of four months from June 2019 to September 2019.

Sample Analysis: The vegetable samples were ovendried at $100^{\circ} \mathrm{C}$ then ground into powdered form. Portions of $1.5 \mathrm{~g}$ of vegetable powder sample were digested in $15 \mathrm{~mL}$ tri acid mixture $\left(65 \% \mathrm{HNO}_{3}, 70 \%\right.$ $\mathrm{HClO}_{4}, 34.37 \% \mathrm{HCl}, 5: 1: 1$ ratio) at $150{ }^{\circ} \mathrm{C}$ in a microwave oven until a transparent solution appeared. The digests were then passed through a pre-washed filter and $15 \mathrm{~mL}$ of the filtrate made up to $250 \mathrm{~mL}$ (Mohsin et al., 2019). The filtrate of vegetables was then analyzed for $\mathrm{Cd}, \mathrm{Pb}, \mathrm{Cr}, \mathrm{Zn}$, and $\mathrm{Cu}$ concentrations using inductively coupled plasma mass spectrometer (ICP-MS).

Statistical Analysis: The data obtained was analyzed using Minitab Statistical software, version 19. The significant difference $(\mathrm{p} \leq 0.05)$ of heavy metal concentrations in vegetables among the different sampling sites was tested using one way-analysis of variance (ANOVA). The heavy metal concentrations obtained were compared with WHO limits to inform the suitability of the vegetables for human consumption.

\section{RESULTS AND DISCUSSION}

Heavy Metal Concentration in Spinach: Cadmium: Concentration of $\mathrm{Cd}$ in spinach samples from the different market sampling sites ranged between 0.055 $\pm 0.08 \mathrm{mg} / \mathrm{kg}$ and $0.172 \pm 0.18 \mathrm{mg} / \mathrm{kg}$. All $\mathrm{Cd}$ values in spinach were within $0.2 \mathrm{mg} / \mathrm{kg}$ WHO permissible levels (Stan, 2009). The level of $\mathrm{Cd}$ in spinach in the farming sites varied between $0.575 \pm 1.01 \mathrm{mg} / \mathrm{kg}$ and $0.013 \pm 0.02 \mathrm{mg} / \mathrm{kg}$ (Table 1). Spinach at site A exceeded WHO set limit for $\mathrm{Cd}$ in leafy vegetables while at site B, C, and D were within WHO safe limits. This is an indication that spinach at site A are likely to have adverse health implications concerning $\mathrm{Cd}$. Cadmium in vegetables is transferred to the human body by ingestion and subsequently distributed by the circulation system to many body organs such as the liver, kidney, lungs and finally bringing harm to these organs (Shi et al., 2020). The concentration of $\mathrm{Cd}$ recorded in this study is lower than the concentration of $\mathrm{Cd}$ in spinach $(3.89 \pm 0.17-4.13 \pm 0.14 \mathrm{mg} / \mathrm{kg})$ recorded in a previous study of spinach vegetables in Saudi Arabian markets (Ali and Al-Qahtani, 2012). Lower values of $\mathrm{Cd}$ concentration in vegetables $(0.0018-3.6580 \mathrm{mg} / \mathrm{kg})$ were also reported in a study carried out in polluted areas in China (Shi et al., 2020). Values of Cd recorded by Heshmati et al., 2020 for a study in western Iran agree with the levels recorded in this study. (Khan et al., 2019) also reported levels of $\mathrm{Cd}(0.203-1.575 \mathrm{mg} / \mathrm{kg})$ that are comparable to $\mathrm{Cd}$ values obtained in this study.

\begin{tabular}{|c|c|c|c|c|c|c|}
\hline \multicolumn{2}{|l|}{ Sampling } & \multicolumn{5}{|c|}{ Mean \pm Std Dex $(\mathrm{mg} / \mathrm{Kg})$} \\
\hline Site & $\mathrm{N}$ & Cadmium (Cd) & Copper (Cu) & Lead $(\mathrm{Pb})$ & Zinc (Zn) & Chromium (Cr) \\
\hline SPM 1 & 4 & $0.172 \pm 0.18$ & $4.70 \pm 4.41$ & $0.439 \pm 0.51$ & $20.7 \pm 24.70$ & $4.43=9.72$ \\
\hline SPM 2 & 4 & $0.055=0.08$ & $4.93=2.97$ & $0.098=0.22$ & $12.14=11.31$ & $1.80=3.87$ \\
\hline OAM & 4 & $0.106=0.09$ & $3.923 \pm 2.16$ & $0.867 \pm 1.16$ & $17.94 \pm 15.49$ & $4.24 \pm 8.90$ \\
\hline Site A & 4 & $0.575=1.01$ & $7.56 \pm 6.58$ & $0.367=0.30$ & $8.32=10.50$ & $1.24=1.47$ \\
\hline Site $\mathbf{B}$ & 4 & $0.069=0.14$ & $3.79 \pm 2.02$ & $0.439=0.63$ & $17.94=14.88$ & $0.368 \pm 0.59$ \\
\hline Site C & 4 & $0.013 \pm 0.03$ & $4.50 \pm 2.16$ & $0.243 \pm 0.19$ & $8.99 \pm 7.57$ & $0.497 \pm 0.87$ \\
\hline Site D & 4 & $0.127=0.23$ & $5.55=4.05$ & $1.49=2.68$ & $12.42=6.78$ & $3.49=4.60$ \\
\hline WHO Set & & 0.2 & 10.0 & 0.3 & 5.0 & 2.3 \\
\hline p-value & & 0.469 & 0.229 & 0.773 & 0.923 & 0.908 \\
\hline
\end{tabular}

Copper: The results of copper concentration in spinach vegetables in the different sampling sites are presented in Table 1. The mean concentration of $\mathrm{Cu}$ in spinach for the market sites ranged between $3.923 \pm$ $2.16 \mathrm{mg} / \mathrm{kg}$ and $4.93 \pm 2.97 \mathrm{mg} / \mathrm{kg}$. Mitheu urban stream sites recorded levels of $\mathrm{Cu}$ ranging from $3.79 \pm$ $2.02 \mathrm{mg} / \mathrm{kg}$ to $7.56 \pm 6.58 \mathrm{mg} / \mathrm{kg}$. The values of $\mathrm{Cu}$ in spinach from all the market sites and all the farm sites were within WHO permissible limits hence the spinach grown and sold in the market sites had no health risk exposure to the consumers. Spinach showed the highest concentration of $\mathrm{Cu}$ at site $\mathrm{A}$. Continued irrigation over a long period could further have laced the soils with $\mathrm{Cu}$ contributing to the high $\mathrm{Cu}$ content in spinach grown downstream. The presence of copper in the vegetables could be attributed to sewage used in irrigating the vegetables, fertilizers and pesticides applied in the growing of the vegetables and some $\mathrm{Cu}$ naturally occurring in the soil in form of minerals. Values obtained in this study are similar to values obtained in previous studies; (2.39$10.19 \mathrm{mg} / \mathrm{kg}$ ) in Lagos metropolis, Nigeria for 
vegetables in different markets (Adedokun et al., 2016) and $0.041-0.829 \mathrm{mg} / \mathrm{kg}$ for vegetables in Tehran supermarkets (Alimohammadi et al., 2018). Sayo et al., 2020 reported similar concentrations of $\mathrm{Cu}$ in spinach vegetables $(1.372 \pm 0.180-4.084 \pm 0.353$ $\mathrm{mg} / \mathrm{kg}$ ) irrigated with wastewater in Embu, Kenya. Results in this study are much higher than those recorded (0.81-0.98 $\mathrm{mg} / \mathrm{kg}$ ) in Sahiwal, Pakistan (Mohsin et al., 2019).

Lead: The concentration of lead in spinach ranged from $0.098 \pm 0.22 \mathrm{mg} / \mathrm{kg}$ to $0.867 \pm 1.16 \mathrm{mg} / \mathrm{kg}$ for the market sites. The level of $\mathrm{Pb}$ in spinach from SPM 1 and the open-air market exceeded WHO acceptable limits while $\mathrm{Pb}$ in spinach from SPM 2 was within WHO set limit. Concentration of lead in spinach grown along the urban stream varied between $0.243 \pm$ $0.19 \mathrm{mg} / \mathrm{kg}$ and $1.49 \pm 2.68 \mathrm{mg} / \mathrm{kg}$. The highest concentration of $\mathrm{Pb}$ in spinach was at site $\mathrm{D}$ and the lowest $\mathrm{Pb}$ concentration at site $\mathrm{C}$. Based on these findings it can be stated that spinach from SPM 1 and the open-air market had hazardous health implications to the consumers. The level of $\mathrm{Pb}$ in spinach from sites A, B and D all exceeded WHO acceptable limit thus the spinach from those sampling points were not fit for human consumption. This indicated that irrigation farming of spinach along Mitheu stream produced heavily contaminated vegetables unfit for human consumption. Excess intake of $\mathrm{Pb}$ has been associated with cardiovascular, kidney, nervous and bone diseases (Shaheen et al., 2016; Chauhan and Chauhan, 2014;Stan, 2009). $\mathrm{Pb}$ in the vegetables could be emanating from different sources such as use of wastewater to irrigate the vegetables, petroleum products and automobile emissions. A study on heavy metal concentration in vegetables in the local market of Jordan recorded similar levels (0.072-0.289 mg/kg) of $\mathrm{Pb}$ in spinach (Osaili et al., 2016). Comparable $\mathrm{Pb}$ values $(0.063-0.75 \mathrm{mg} / \mathrm{kg})$ were also reported for spinach vegetables grown in Pakistan (Mohsin et al., 2019). On the contrary, lower $\mathrm{Pb}$ values $(0.022-0.04$ $\mathrm{mg} / \mathrm{kg}$ ) were reported in a study carried out in western Iran which were within WHO recommended levels. Results obtained in this study are higher than those recorded by Sayo et al., 2020 for spinach $(0.02-0.168$ $\mathrm{mg} / \mathrm{kg}$ ) irrigated with wastewater in Embu, Kenya.

Zinc: $\mathrm{Zn}$ concentration in spinach ranged from 12.14 $\pm 11.31 \mathrm{mg} / \mathrm{kg}$ to $20.7 \pm 24.7 \mathrm{mg} / \mathrm{kg}$ from the market sites. On the other hand, the levels of $\mathrm{Zn}$ in spinach for the different sampling sites along Mitheu stream were $8.32 \mathrm{mg} / \mathrm{kg}, 17.94 \mathrm{mg} / \mathrm{kg}, 8.99 \mathrm{mg} / \mathrm{kg}$ and 12.42 $\mathrm{mg} / \mathrm{kg}$. Concentration of $\mathrm{Zn}$ among Mitheu stream sampling sites decreased as; site $\mathrm{B}>$ site $\mathrm{D}>$ site $\mathrm{C}$ $>$ site A. Concentration of $\mathrm{Zn}$ in spinach from the market sites and those from Mitheu stream sites exceeded WHO safe limit and thus spinach from these sites were likely to have harmful health effects occasioned by $\mathrm{Zn}$ poisoning. Zinc is an essential nutrient for body growth and development when used in the recommended proportions. Excessive intake of zinc as determined in this study could lead to stomach cramps, nausea, vomiting and diarrhea (Saskatchewan, 2007; Wei et al., 2019). The presence of $\mathrm{Zn}$ in the vegetables could be associated with the use of wastewater for irrigation, contaminated soil and fertilizers and pesticides used in vegetable growing. Results in this study indicated lower zinc levels when compared with those recorded in a previous study $(23.8-89.8 \mathrm{mg} / \mathrm{kg})$ carried out in Maun market, Botswana (Bati et al., 2016). Lower values of Zn (3.77 $-16.3 \mathrm{mg} / \mathrm{kg}$ ) than those obtained in this study were reported in a previous study in Banat County, Romania (Harmanescu et al, 2011). Higher $\mathrm{Zn}$ concentrations in spinach grown $2.31-9.4 \mathrm{mg} / \mathrm{kg}$ and $1.141-3.57$ $\mathrm{mg} / \mathrm{kg}$ were also reported by Mohsin et al., (2019)and Sayo et al., (2020) respectively.

Chromium: Spinach vegetables from the market sites showed varying $\mathrm{Cr}$ concentrations of $1.80 \pm 3.87$ $\mathrm{mg} / \mathrm{kg}$ to $4.43 \pm 9.72 \mathrm{mg} / \mathrm{kg}$. This study revealed that spinach from SPM 1 and OAM had accumulated $\mathrm{Cr}$ level higher than the WHO permissible level. Cr levels in spinach grown along the Mitheu urban stream ranged from $0.368-3.49 \mathrm{mg} / \mathrm{kg}$. Cr concentration in Spinach from site A were within the WHO safe levels while those from sites B, C and D exceeded the WHO acceptable limits. This study showed that spinach from sampling sites that exceeded the recommended $\mathrm{Cr}$ limits were not safe for human consumption and human health risks were thus inevitable with the consumption of these vegetables. Various scientists have also reported elevated levels of $\mathrm{Cr}$ in wastewater irrigated vegetables. The results obtained in this study showed similar $\mathrm{Cr}$ contents in spinach to those reported by Pan et al., (2016) and Osaili et al., (2016), who also reported that $\mathrm{Cr}$ concentration in spinach $(0.057-3.51 \mathrm{mg} / \mathrm{kg})$ exceeding the recommended international standards. A similar level of $\mathrm{Cr}(1.96$ $\mathrm{mg} / \mathrm{kg}$ ) was also found in wastewater irrigated spinach samples collected from western region of Saudi Arabia. In contrast, a lower concentration of $\mathrm{Cr}$ was found $(0.27 \mathrm{mg} / \mathrm{kg})$ in wastewater irrigated spinach in Sao Paulo state, Brazil (Guerra et al., 2012).

Heavy Metal Concentration in Kales: Cadmium: The mean and standard deviation of $\mathrm{Cd}$ concentration in the kale samples in the different sampling sites were; $0.113 \pm 0.11 \mathrm{mg} / \mathrm{kg}$ in SPM $1,0.013 \pm 0.03 \mathrm{mg} / \mathrm{kg}$ in SPM 2 while kale from OAM had Cd below detectable limit (BDL). The mean concentration of $\mathrm{Cd}$ in kales in the market sites varied in the order SPM 1> SPM 2> 
Open air market. All Cd mean values in kale collected from the market sites were within $0.2 \mathrm{mg} / \mathrm{kg}$ WHO set limit (Stan, 2009), implying they were not contaminated with $\mathrm{Cd}$ and were thus safe for human consumption. The mean concentration of $\mathrm{Cd}$ in kale from the Mitheu urban stream sites ranged from 0.058 $\pm 0.09 \mathrm{mg} / \mathrm{kg}$ to $0.319 \pm 0.56 \mathrm{mg} / \mathrm{kg}$ (Table 2). Site D had the highest $\mathrm{Cd}$ concentration in kales while site $\mathrm{A}$ had the lowest level of Cd (BDL). All the mean values of $\mathrm{Cd}$ in kales were within WHO acceptable standards except for kale collected from site D which slightly exceeded the WHO limit for Cd in leafy vegetables. High level of Cd at site D could be associated with the raw sewage that drains to the Mitheu stream from vandalized sewer lines. There was no significant variation of $\mathrm{Cd}$ concentration in the different sampling sites $(\mathrm{p}>0.05)$. Concentration of $\mathrm{Cd}$ obtained in this study agrees with $\mathrm{Cd}$ levels reported for kale grown in Jos, Nigeria $(0.061 \pm 0.03 \mathrm{mg} / \mathrm{kg})$ and $0.18-0.29$ $\mathrm{mg} / \mathrm{kg}$ reported in Koka and Wonji farms in Ethiopia (Lapshak et al., 2019; Eliku and Leta, 2017). Higher Cd concentrations $(0.34-3.5 \mathrm{mg} / \mathrm{kg})$ were however reported in a similar study in Kitui, Kenya (Wambua et al., 2018) and $0.67 \mathrm{mg} / \mathrm{kg}$ in Harar town, Ethiopia (Alamnie et al., 2020).

Table 2: Mean \pm standard deviation of heavy metal concentration $(\mathrm{mg} / \mathrm{kg})$ in kales and WHO recommended levels

\begin{tabular}{|c|c|c|c|c|c|c|}
\hline \multirow{2}{*}{ Sampling Site } & \multicolumn{3}{|c|}{ Mean \pm StDev (mg/Kg) } & \multirow[b]{2}{*}{ Lead $(\mathrm{Pb})$} & \multirow[b]{2}{*}{ Zinc $(\mathrm{Zn})$} & \multirow[b]{2}{*}{ Chromium $(\mathrm{Cr})$} \\
\hline & $\mathrm{N}$ & Cadmium $(\mathrm{Cd})$ & Copper $(\mathrm{Cu})$ & & & \\
\hline SPM 1 & 4 & $0.113 \pm 0.11$ & $1.706 \pm 1.47$ & $0.331 \pm 0.57$ & $17.86 \pm 18.13$ & $0.112 \pm 0.25$ \\
\hline SPM 2 & 4 & $0.013 \pm 0.03$ & $0.971 \pm 1.40$ & $0.236 \pm 0.44$ & $26.7 \pm 24.00$ & $14.0 \pm 26.90$ \\
\hline OAM & 4 & BDL & $0.971 \pm 0.89$ & $0.156 \pm 0.19$ & $11.06 \pm 11.34$ & $0.280 \pm 0.56$ \\
\hline Site A & 4 & BDL & $0.468 \pm 0.94$ & BDL & $15.4 \pm 24.10$ & $0.104 \pm 0.21$ \\
\hline Site $B$ & 4 & $0.058 \pm 0.09$ & $1.630 \pm 2.05$ & $0.368 \pm 0.56$ & $19.28 \pm 14.54$ & $2.86 \pm 4.19$ \\
\hline Site C & 4 & $0.067 \pm 0.08$ & $1.630 \pm 2.14$ & BDL & $16.15 \pm 13.30$ & BDL \\
\hline Site D & 4 & $0.319 \pm 0.56$ & $1.085 \pm 1.26$ & $0.020 \pm 0.04$ & $5.78 \pm 6.74$ & BDL \\
\hline WHO Set & & 0.2 & 10.0 & 0.3 & 5.0 & 2.3 \\
\hline P-value & & 0.391 & 0.571 & 0.577 & 0.934 & 0.497 \\
\hline
\end{tabular}

Copper: Concentration of copper in kales in the market sites ranged between $0.971 \pm 0.89 \mathrm{mg} / \mathrm{kg}$ and $1.706 \pm 1.47 \mathrm{mg} / \mathrm{kg}$. Farming sites along the urban Mitheu stream recorded levels of $\mathrm{Cu}$ ranging from $0.468 \pm 0.94 \mathrm{mg} / \mathrm{kg}$ to $1.630 \pm 2.14 \mathrm{mg} / \mathrm{kg}$. The highest mean $\mathrm{Cu}$ concentration in kale from the farm sites was recorded at site $\mathrm{C}$, a farm along Mitheu stream just after sewage treatment plant. The level of concentrations of $\mathrm{Cu}$ in kale from all the different sampling sites was within WHO permissible level thus the kale sold in the market sites and that grown along Mitheu stream was not contaminated with $\mathrm{Cu}$ and had no health risk hazard to the consumers. Results showed no significant difference in $\mathrm{Cu}$ concentrations among the sampling sites $(p>0.05)$. Concentration of $\mathrm{Cu}$ in kale recorded in this study compares well with previous $\mathrm{Cu}$ concentration $(0.48 \mathrm{mg} / \mathrm{kg})$ in kale in Makongeni market, Thika (Maina et al., 2019). Zhang et al., (2018) also recorded similar Cu levels for kales grown in Pearl River Delta, South China. Contrarily, Lapshak et al., (2019) recorded higher $\mathrm{Cu}$ concentration $(1.892 \pm 0.01 \mathrm{mg} / \mathrm{kg})$.

Lead: The mean concentration of $\mathrm{Pb}$ in kales from the three market sampling sites ranged from $0.156 \pm 0.19$ $\mathrm{mg} / \mathrm{kg}$ to $0.33 \pm 0.57 \mathrm{mg} / \mathrm{kg}$. $\mathrm{Pb}$ concentration in kales from SPM 2 and the open-air market was within WHO safe limit while $\mathrm{Pb}$ in kales from SPM1 exceeded WHO permissible limit for $\mathrm{Pb}$ in leafy vegetables. It is thus deducible that kales from SPM 1 were not safe for consumers as they exposed the consumers to unsafe $\mathrm{Pb}$ levels. On the other hand, mean concentration of lead in kale grown along Mitheu urban stream was $0.02 \pm 0.04 \mathrm{mg} / \mathrm{kg}$ in site $\mathrm{D}$ and $0.368 \pm 0.56 \mathrm{mg} / \mathrm{kg}$ in site $\mathrm{B}$. However, the level of $\mathrm{Pb}$ in kale from site $\mathrm{A}$ and site $\mathrm{C}$ was below detectable limit. Kale had the highest concentration of $\mathrm{Pb}$ at site $\mathrm{B}$ and the lowest at site $\mathrm{D}$. The level of $\mathrm{Pb}$ in kale from site $\mathrm{B}$ exceeded WHO acceptable limit thus the kale from sampling site $\mathrm{B}$ were contaminated with $\mathrm{Pb}$ and were likely to have health implications. Concentration of $\mathrm{Pb}$ in the various sampling sites did not show any significant variation $(\mathrm{p}>0.05)$. Similar $\mathrm{Pb}$ concentrations $(0.37-0.45$ $\mathrm{mg} / \mathrm{kg}$ ) were reported in Koka and Wonji farms, Ethiopia (Eliku and Leta, 2017). Higher mean $\mathrm{Pb}$ values $(0.25-6.125 \mathrm{mg} / \mathrm{kg})$ were reported for kale sold in markets and supermarkets of Semarang city (Inandin and Arminsih, 2020). Wambua et al., (2018) also reported higher mean $\mathrm{Pb}$ levels (12.37 - 20.33 $\mathrm{mg} / \mathrm{kg}$ ) for kale irrigated with wastewater in Kitui county, Kenya.

Zinc: Results showed mean concentration of $\mathrm{Zn}$ in kale from the market sites varied from $11.06 \pm 11.34$ $\mathrm{mg} / \mathrm{kg}$ to $26.7 \pm 24.00 \mathrm{mg} / \mathrm{kg}$. Farm sites along Mitheu stream recorded $\mathrm{Zn}$ mean concentration of $15.4 \mathrm{mg} / \mathrm{kg}$, $19.28 \mathrm{mg} / \mathrm{kg}, 16.15 \mathrm{mg} / \mathrm{kg}$, and $5.78 \mathrm{mg} / \mathrm{kg}$ in sampling sites $\mathrm{A}, \mathrm{B}, \mathrm{C}$, and $\mathrm{D}$ respectively. Concentration of $\mathrm{Zn}$ among the sampling sites decreased as; site $\mathrm{B}>$ site $\mathrm{C}>$ site $\mathrm{A}>$ site $\mathrm{D}$. Concentrations of Zinc in kale both grown and sold in the different sampling sites exceeded WHO 
permissible levels for $\mathrm{Zn}$ in leafy vegetables. This indicated that the kale had high zinc concentration exposing the consumers to harmful health effects. Compared to previous studies, mean concentrations of $\mathrm{Zn}$ in kale obtained in this study were higher compared to $\mathrm{Zn}$ values reported in previous studies; $4.85 \mathrm{mg} / \mathrm{kg}$ for kale sold in Makongeni market in Thika (Maina et al., 2019), $4.61-5.13 \mathrm{mg} / \mathrm{kg}$ for kale grown in Koka and Wonji farms, Ethiopia (Eliku and Leta, 2017) and $0.0154 \pm 0.007 \mathrm{mg} / \mathrm{kg}$ for kale grown in farms along river Moiben, Uasin Gishu (Akenga et al., 2020).

Chromium: Kale samples from the market sites showed mean $\mathrm{Cr}$ concentrations in the range $0.112 \pm$ $0.25 \mathrm{mg} / \mathrm{kg}$ to $14.0 \pm 26.9 \mathrm{mg} / \mathrm{kg}$. The level of concentration of $\mathrm{Cr}$ in kale from SPM 2 was higher than the recommended $\mathrm{Cr}$ levels in leafy vegetables. The mean $\mathrm{Cr}$ concentration levels in the kale grown along the Mitheu urban stream were; $0.104 \pm 0.21$ $\mathrm{mg} / \mathrm{kg}$ at site A and $2.86 \mathrm{mg} / \mathrm{kg}$ at site B. Kales grown at sites $\mathrm{A}$ and $\mathrm{D}$ did not have detectable concentrations of $\mathrm{Cr}$, the concentration was possibly below detectable limit (BDL). Kales from sites A, C and D were safe for human consumption with regard to WHO recommended levels of $\mathrm{Cr}$ in leafy vegetables. Kale vegetables from site D exceeded WHO standard limits and thus were not fit for consumption. Lapshak et al., (2019) recorded comparable $\mathrm{Cr}$ levels $(0.511 \pm 0.01$ $\mathrm{mg} / \mathrm{kg}$ ) to those obtained in this study. A similar study in farms along Moiben River recorded lower $\mathrm{Cr}$ means $(0.00141 \mathrm{mg} / \mathrm{kg})$ in kales compared to $\mathrm{Cr}$ levels recorded in this study (Akenga et al., 2020).

Correlation of heavy metal concentration in Kales and Spinach: Pearson correlation was applied to explore the degree of association of the heavy metals in the vegetables (Table 3). Cd in kales was found to be positively and significantly correlated to $\mathrm{Pb}$ in spinach $(\mathrm{r}=0.772, \mathrm{p}=0.042)$. There was a significant positive correlation in $\mathrm{Pb}$ in kales and $\mathrm{Zn}$ in spinach $(\mathrm{r}=0.821$, $\mathrm{p}=0.024)$. $\mathrm{Zn}$ in kales showed positive significant correlation to $\mathrm{Cr}$ in kales $(\mathrm{r}=0.772, \mathrm{p}=0.042) . \mathrm{Cd}$ in spinach also significantly correlated to $\mathrm{Cu}$ in spinach $(\mathrm{r}=0.882, \mathrm{p}=0.009)$. On the other hand, $\mathrm{Pb}$ in spinach had a negative significant correlation to $\mathrm{Zn}$ in kales ( $\mathrm{r}$ $=0.889, \mathrm{p}=0.007$ ).

Table 3: Pearson correlation of heavy metals in spinach and kales

\begin{tabular}{|c|c|c|c|c|c|c|c|c|c|c|}
\hline & $\begin{array}{l}\mathrm{Cd} \\
\text { kales }\end{array}$ & $\begin{array}{l}\mathrm{Cu} \\
\text { kales }\end{array}$ & $\begin{array}{l}\mathrm{Pb} \\
\text { kales }\end{array}$ & $\begin{array}{l}\mathrm{Zn} \\
\text { kales }\end{array}$ & $\begin{array}{l}\mathrm{Cr} \\
\text { kales }\end{array}$ & $\begin{array}{l}\mathrm{Cd} \\
\text { spinach }\end{array}$ & $\begin{array}{l}\mathrm{Cu} \\
\text { spinach }\end{array}$ & $\begin{array}{l}\mathrm{Pb} \\
\text { spinach }\end{array}$ & $\begin{array}{l}\mathrm{Zn} \\
\text { spinach }\end{array}$ & $\begin{array}{l}\mathrm{Cr} \\
\text { spinach }\end{array}$ \\
\hline Cd kales & 1 & & & & & & & & & \\
\hline Cu kales & 0.215 & 1 & & & & & & & & \\
\hline $\mathrm{Pb}$ kales & -0.208 & 0.513 & 1 & & & & & & & \\
\hline $\begin{array}{l}\mathrm{Zn} \text { kales } \\
\mathrm{Cr} \text { kales }\end{array}$ & -0.615 & 0.149 & 0.538 & 1 & & & & & & \\
\hline $\begin{array}{l}\text { Cr kales } \\
\text { Cd spinach }\end{array}$ & -0.301 & -0.154 & 0.343 & $0.772^{+}$ & 1 & & & & & \\
\hline $\begin{array}{l}\text { Cd spmach } \\
\text { Cu spinach }\end{array}$ & -0.198 & -0.682 & -0.349 & -0.143 & -0.286 & 1 & & & & \\
\hline $\begin{array}{l}\text { Cu spimach } \\
\mathrm{Pb} \text { spinach }\end{array}$ & 0.046 & -0.722 & -0.587 & -0.143 & -0.110 & $0.882^{+}$ & 1 & & & \\
\hline $\begin{array}{l}\text { Pb spinach } \\
\text { Zn spinach }\end{array}$ & $0.772^{+}$ & -0.138 & -0.292 & $-0.889^{\circ}$ & -0.464 & -0.041 & 0.017 & 1 & & \\
\hline $\mathrm{Zn}$ spinach & 0.027 & 0.509 & $0.821^{+}$ & 0.025 & -0.098 & -0.338 & -0.643 & 0.146 & 1 & \\
\hline $\mathrm{Cr}$ spinach & 0.327 & -0.045 & 0.127 & -0.426 & -0.218 & -0.033 & -0.114 & 0.546 & 0.566 & 1 \\
\hline
\end{tabular}

*. Correlation is significant at the 0.05 level (2-tailed).

The results showed that $\mathrm{Cd}, \mathrm{Pb}, \mathrm{Zn}, \mathrm{Cu}$ and $\mathrm{Cr}$ could be associated to each other and might originate from common sources. Heavy metals do not degrade and cannot disintegrate into less toxic constituent and thus accumulate where they are deposited or released (Lapshak et al., 2019). Leafy vegetables grown in heavy metal contaminated areas accumulate higher amounts of heavy metals as they are said to be good absorbers of the heavy metals (Bett et al., 2019).

Conclusion: This current study revealed there was significant heavy contamination of kales and spinach grown along Mitheu stream and those sold in Machakos municipality largely due to concentration of $\mathrm{Cd}, \mathrm{Cr}, \mathrm{Pb}$ and $\mathrm{Zn}$ that were above WHO critical values. There is thus need for regular monitoring of heavy metal contamination in vegetables within Machakos town and its environs to prevent human health risks associated with consumption of vegetables grown in urban areas.

Acknowledgment: The authors express gratitude to Machakos University for financial support through the internal research and innovation grant and Kenya Plant Health Services (KEPHIS), Nairobi for availing laboratory facility for analysis of samples.

\section{REFERENCES}

Adedokun, A H;Njoku, KL; Akinola, MO; Adesuyi, AA; Jolaoso, AO (2016). Potential human health risk assessment of heavy metals intake via consumption of some leafy vegetables obtained from four market in Lagos Metropolis, Nigeria. Journal of Applied Sciences and Environmental Management, 20(3), 530.

Akenga, T; Ayabei, K; Kerich, E; Sudoi, V; Kuya, C 
(2020). Evaluation of Levels of Selected Heavy Metals in Kales, Soils and Water Collected from Irrigated Farms along River Moiben, Uasin-Gishu County, Kenya. Journal of Geoscience and Environment Protection, 08(02), 144-155

Alamnie, G; Kebede, A; Menkir, S(2020). Heavy Metal Contamination in Green Leafy Vegetables Irrigated with Heavy Metal Contamination in Green Leafy Vegetables Irrigated with Wastewater Collected from Harar Town Vegetable Farm, Ethiopia. Food Science and Quality Management, 94 (June).

Alghobar, MA; Suresha, S (2017). Evaluation of metal accumulation in soil and tomatoes irrigated with sewage water from Mysore city, Karnataka, India. Journal of the Saudi Society of Agricultural Sciences, 16(1), 49-59.

Ali, MH; Al-Qahtani, KM (2012). Assessment of some heavy metals in vegetables, cereals and fruits in Saudi Arabian markets. Egyptian Journal of Aquatic Research, 38(1), 31-37.

Alimohammadi, M; Younesian, M; Madihi, BS; Nabizadeh NR; Jahed GR; Hadi, M; Ghanbari, F (2018). Heavy metal(oid)s concentration in Tehran supermarket vegetables: carcinogenic and non-carcinogenic health risk assessment*. Toxin Reviews, 0(0), 1-8

Arora, M; Kiran, B; Rani, S; Rani, A; Kaur, B; Mittal, $N$ (2008). Heavy metal accumulation in vegetables irrigated with water from different sources. Food Chemistry, 111(4), 811-815.

Balkhair, KS; Ashraf, MA (2016). Field accumulation risks of heavy metals in soil and vegetable crop irrigated with sewage water in western region of Saudi Arabia. Saudi Journal of Biological Sciences, 23(1), S32-S44.

Bati, K; Mogobe, O; Masamba, WL (2016). Concentrations of Some Trace Elements in Vegetables Sold at Maun Market, Botswana. J. Food Res.6(1), 69

Bett, L; Gilbert, O; Phanice, W; Mule, S (2019). Determination of Some Heavy Metals in Soils and Vegetables Samples from Kericho West Subcounty, Kenya. Chem. Sci. Inter. J.28(2), 1-10.

Bi, C; Zhou, Y; Chen, Z; Jia, J; Bao, X (2018). Heavy metals and lead isotopes in soils, road dust and leafy vegetables and health risks via vegetable consumption in the industrial areas of Shanghai, China. Science of the Total Environment, 619620, 1349-1357

Chauhan, G; Chauhan, U (2014). Human health risk assessment of heavy metals via dietary intake of vegetables grown in wastewater. International Journal of Scientific and Research Publications, 4(9), 1-9.

Eliku, T; Leta, S (2017). Heavy metals bioconcentration from soil to vegetables and appraisal of health risk in Koka and Wonji farms , Ethiopia.Environ Sci Pollut Reshttps://doi.org/10.1007/s11356-017-8843-6

Guerra, F; Ricardo TA; Muraoka, T; Chaves MN; Guidolin CBS (2012). Guerra et al. Heavy metals in food chain Heavy metals in vegetables and potential risk for human health. Scientia Agricola, 69(1), 54-60.

Harmanescu, M; Alda, LM; Bordean, DM; Gogoasa, I; Gergen, I (2011). Heavy metals health risk assessment for population via consumption of vegetables grown in old mining area; a case study: Banat County, Romania. Chemistry Central Journal, 5(1), 1-10

Heshmati, A; Mehri, F; Karami-Momtaz, J; Khaneghah, AM (2020). Concentration and risk assessment of potentially toxic elements, lead and cadmium, in vegetables and cereals consumed in western Iran. J. Food Protect.83(1), 101-107

Hussain, A; Priyadarshi, M; Dubey, S (2019). Experimental study on accumulation of heavy metals in vegetables irrigated with treated wastewater. Applied Water Science, 9(5), 1-11.

Ikenaka, Y; Nakayama, SMM; Muzandu, K; Choongo, K; Teraoka, H; Mizuno, N; Ishizuka, M (2014). Heavy metal contamination of soil and sediment in Zambia. Heavy Metal Contamination of Water and Soil: Analysis, Assessment, and Remediation Strategies, 4(11), 109-128. https://doi.org/10.1201/b16566

Inandin, P; Arminsih, R (2020). Health risk analysis of lead levels ( $\mathrm{pb}$ ) in green leafy vegetables from traditional markets and supermarket in semarang city : a preliminary study. Jurnal Riset Kesehatan 9(2), 65-71.

Jaishankar, M; Tseten, T; Anbalagan, N; Mathew, BB; Beeregowda, KN (2014). Toxicity, mechanism 
and health effects of some heavy metals. Interdisciplinary Toxicology, 7(2), 60-72

Kacholi, DS; Sahu, M (2018). Levels and Health Risk Assessment of Heavy Metals in Soil, Water, and Vegetables of Dar es Salaam, Tanzania. Hindawi Journal of Chemistry.2018.

Khan, S; Cao, Q; Zheng, Y. M; Huang, YZ; Zhu, YG (2008). Health risks of heavy metals in contaminated soils and food crops irrigated with wastewater in Beijing, China. Environmental Pollution, 152(3), 686-692.

Khan, ZI; Nisar, A; Ugulu, I; Ahmad, K; Bashir, H; Dogan, Y (2019). Egyptian Journal of Botany. 59(3), 753-762

Kombe, WJ (2005). Land use dynamics in peri-urban areas and their implications on the urban growth and form: The case of Dar es Salaam, Tanzania. Habitat International, 29(1), 113-135.

Lapshak, J; Gabriel, N; Mary, M; Panshak, R (2019). Heavy metal contamination in selected cruciferous vegetables grown in Jos, Nigeria. International J. Cu. Res. Chem. 5(4) 5213 - 5221.

Maina, S; Anyango, V; Yan, X; Wahiti, R; Wang, Q; Wang, J (2019). Health risk assessment by consumption of vegetables irrigated with reclaimed waste water: A case study in Thika ( Kenya ). J. Environ. Manage.231, 576-581

Mohsin, S; Andleeb, S; Mahmood, A (2019). Ecological risk assessment of heavy metals in vegetables irrigated with groundwater and wastewater: The particular case of Sahiwal district in Ecological risk assessment of heavy metals in vegetables irrigated with groundwater and wastewater. Agric. Wat. Manage.226(October),

Osaili, TM; Jamali, AF; Makhadmeh, IM; Jarrar, SK (2016). Heavy metals in vegetables sold in the local market in Jordan. 3210(April).

Pan, X; Wu, P; Jiang, X (2016). Levels and potential health risk of heavy metals in marketed vegetables in Zhejiang, China. Nature Publishing Group, (February), 1-7

Ray, S; Kanti Ray, M (2009). Bioremediation Of Heavy Metal Toxicity-With Special Reference To
Chromium. Al Ameen J Med Sei, 2(9), 4-1.

Saskatchewan, G (2007). Zinc (For Private Water and Health Regulated Public Water Supplies) How Does Zinc Get Into Water? How Can I Remove Zinc From My Drinking Water? Retrieved from http://www.swa.ca/AboutUs/Contact.asp?type= Offices

Sayo, S; Kiratu, JM; Nyamato, GS (2020). Heavy metal concentrations in soil and vegetables irrigated with sewage effluent: A case study of Embu sewage treatment plant, Kenya. Scientific African, 8. https://doi.org/10.1016/j.sciaf.2020.e00337

Shaheen, N; Irfan, NM; Khan, IN; Islam, S; Islam, MS; Ahmed, MK (2016). Presence of heavy metals in fruits and vegetables: Health risk implications in Bangladesh. Chemosphere, 152(March), 431-438.

Shi, R; Lv, J; Liu, Y (2020). Spatial Distribution and Bio - accumulation of Cadmium and Lead in Soil , Rice and Vegetables in Typical Pollution Areas , China. Bull. Environ. Contam.Toxic.

Stan, C (2009). CODEX STAN 193-1995 Page 1 of 44. Natural Toxins.

Wambua, JM; Korir, N; Ngene, SM (2018). Heavy metal concentration in amaranthus, cowpea, black nightshade and kale in response to wastewater irrigation in Kitui County, Kenya. 3, 1025-1033.

Wei, WK; Kong YC; Nulit, R; Omar, H; Zaharin AA; Hee CW; Seng LC (2019a). Zn in vegetables: A review and some insights. Integrative Food, Nutrition and Metabolism, 6(2), 1-7.

Wei WK; Kong, YC., Nulit, R., Omar, H., Zaharin Aris, A., Hee Cheng, W., ... Seng Leow, C. (2019b). $\mathrm{Zn}$ in vegetables: A review and some insights. Integrative Food, Nutrition and Metabolism, 6(2).

Zhang, J; Li, H; Zhou, Y; Dou, L; Cai, L (2018). Bioavailability and soil-to-crop transfer of heavy metals in farmland soils : A case study in the Pearl River Delta, South China. Environ. Pollut.235, 710-719. 